\title{
A tree-ring perspective on the terrestrial carbon cycle
}

\author{
Authors: Flurin Babst, M. Ross Alexander, Paul Szejner, Olivier \\ Bouriaund, Stefan Klesse, John Roden, Philippe Ciais, Benjamin \\ Poulter, David Frank, David J.P. Moore, Valerie Trouet
}

The final publication is available at Springer via http://dx.doi.org/10.1007/s00442-014-3031-6. This is a postprint of an article that originally appeared in Oecologia on August 14, 2014. Oecologia

Flurin Babst, M. Ross Alexander, Paul Szejner, Olivier Bouriaud, Stefan Klesse, John Roden, Philippe Ciais, Benjamin Poulter, David Frank, David J. P. Moore, Valerie Trouet. "A tree-ring perspective on the terrestrial carbon cycle." Oecologia 176(2): 307-322.

http://dx.doi.org/10.1007/s00442-014-3031-6

Made available through Montana State University's ScholarWorks scholarworks.montana.edu 


\title{
A tree-ring perspective on the terrestrial carbon cycle
}

Flurin Babst, M. Ross Alexander, Paul Szejner, Valerie Trouet: Laboratory of Tree-Ring Research, University of Arizona, Tucson, AZ, USA M. Ross Alexander, David J.P. Moore: School of Natural Resources and the Environment, University of Arizona, Tucson, AZ, USA Olivier Bouriaud: National Forest Inventory, Forest Research and Management Institute Eroilor, Voluntari, Romania, USA Stefan Klesse \& David Frank: Swiss Federal Research Institute WSL, Birmensdorf, Switzerland, USA

Stefan Klesse \& David Frank: Oeschger Center for Climate Change Research, Bern, Switzerland, USA

John Roden: Southern Oregon University, Ashland, Oregon, USA

Philippe Ciais: Laboratoire Des Sciences Du Climat et de L'Environnement, Gif-Sur-Yvette, France

Benjamin Poulter: Institute on Ecosystems, Department of Ecology, Montana State University, Bozeman, MT, USA

\begin{abstract}
Tree-ring records can provide valuable information to advance our understanding of contemporary terrestrial carbon cycling and to reconstruct key metrics in the decades preceding monitoring data. The growing use of tree rings in carbon-cycle research is being facilitated by increasing recognition of reciprocal benefits among research communities. Yet, basic questions persist regarding what tree rings represent at the ecosystem level, how to optimally integrate them with other data streams, and what related challenges need to be overcome. It is also apparent that considerable unexplored potential exists for tree rings to refine assessments of terres-trial carbon cycling across a range of temporal and spatial domains. Here, we summarize recent advances and highlight promising paths of investigation with respect to (1) growth phenology, (2) forest productivity trends and variability, (3) $\mathrm{CO}_{2}$ fertilization and water-use efficiency, (4) forest disturbances, and (5) comparisons between observational and computational forest productivity estimates. We encourage the integration of tree-ring data: with eddy-covarian measurements to investigate carbon allocation patterns and water-use efficiency; with remotely sensed observations to distinguish the timing of cambial growth and leaf phenology; and with forest inventories to develop continuous, annually-resolved and long-term carbon budgets. In addition, we note the potential of tree-ring records and derivatives thereof to help evaluate the performance of earth system models regarding the simulated magnitude and dynamics of forest carbon uptake, and inform these models about growth responses to (non-)climatic drivers. Such efforts are expected to improve our understanding of forest carbon cycling and place current developments into a long-term perspective.
\end{abstract}

\section{Introduction}

Forest growth is one of the key processes that need to be assessed at a global scale to understand and quantify the 
short- to long-term impacts of environmental change on the terrestrial carbon cycle. The total terrestrial carbon sink is currently estimated at $2.5 \pm 0.8 \mathrm{PgC}$ (Le Quéré et al. 2013), with forests contributing $1.1 \pm 0.8 \mathrm{PgC}$ per year (Pan et al. 2011). The considerable uncertainty and the large inter-annual variability associated with the terrestrial carbon sink illustrate that this component of the global carbon cycle is both highly dynamic and remains poorly quantified (Poulter et al. 2014). Investigating the fate of this sink with respect to climate, increasing $\mathrm{CO}_{2}$, nutrient limitation and deposition, and land-cover change is highly relevant for management and political decision making (Fahey et al. 2009), as well as for the well-being of society. This has accordingly been a major research topic over the past years to decades (Bonan 2008). Despite these efforts, our understanding of carbon dynamics in forest ecosystems is still incomplete at large scales as a consequence of uncertainties in carbon allocation patterns (Brüggemann et al. 2011; Litton et al. 2007), forest management effects (Bellassen et al. 2011), and a paucity of long-term data (Reichstein et al. 2013). These uncertainties are manifested in diverging vegetation model predictions (Friedlingstein et al. 2010; Jones et al. 2013), or misfits between model results and observed trends (Keenan et al. 2012). In addition, uncertainties persist regarding forests' response to climate variability (Babst et al. 2013) and disturbances (Running 2008), as well as long-term effects of nitrogen and $\mathrm{CO}_{2}$ fertilization (Gedalof and Berg 2010; Law 2013). Together with human land-use, this array of uncertain factors form a very complex set of drivers for large-scale forest growth, which is challenging to resolve and calls for both long-term and large-scale observational records.

Tree rings are a direct measure of stem growth, which represents the principal above-ground carbon accumulation pool and has significant economic and societal value (Fahey et al. 2009). Because tree growth is sensitive to changes in the physical environment, tree rings have often been used to develop intra-annual to centennial records of environmental and anthropogenic drivers including climate (e.g., Frank et al. 2010), disturbances (Esper et al. 2007), light and nutrient availability (Drever and Lertzman 2001), competition (Weber et al. 2008), or management (Brienen and Zuidema 2006). At present, the International Tree Ring Data Bank (ITRDB) is the largest database of tree-ring data providing access to a variety of parameters from more than 3,000 tree-ring sites across the globe. Existing measurements include (1) earlywood, latewood, and total ring-width, (2) wood density (earlywood, latewood, minimum, and maximum density), (3) blue light reflected from the wood surface (Campbell et al. 2007), (4) stable isotope ratios (i.e. carbon, oxygen, hydrogen, nitrogen) in whole wood, holo-, and alpha-cellulose, (5) wood anatomical features (e.g., number, size and formation of cells, cell lumen, and cell walls), and (6) the abundance of specific chemical compounds (Berger et al. 2004). These data provide extensive information on inter- and intra-annual forest growth dynamics (Babst et al. 2013; Breitenmoser et al. 2014; Briffa et al. 2002; Wettstein et al. 2011) and facilitate a variety of research opportunities to improve understanding of terrestrial carbon cycling.

Here, we review existing literature to identify knowledge gaps where information derived from tree rings can provide insight in the magnitude and variability of the global forest carbon balance and related environmental research. We further encourage the integration of dendroecology with several other disciplines to overcome limitations associated with individual data streams. This may inspire new paths of investigation and broaden the ongoing discussion concerning the terrestrial carbon cycle.

\section{Tree rings in a carbon cycle context}

Tree rings are able to be clearly defined in most extratropical and even many tropical areas where the progression of seasons induces distinct annually rhythmic variability in wood cell structures (Cuny et al. 2014). The cambial cell division, enlargement, and lignification of cell walls that result in the final ring characteristics are influenced by numerous physiological processes that are modulated by environmental conditions both prior to and during the growing season (Fritts 1976). Tree rings are thus the final product of manifold mechanisms related to the energy, water, carbon, and nutrient budgets (Fig. 1). The exact characteristics of the division and maturation of cells may be somewhat dependent upon the growth form and physiology of individual species, but ultimately require the immediate or lagged allocation of carbohydrates (Gessler et al. 2009). At the leaf-level, carbon uptake is largely controlled by light, moisture, temperature, atmospheric $\mathrm{CO}_{2}$, and nutrient availability (Collatz et al. 1991; Farquhar and von Caemmerer 1982). Carbon sequestration further depends on the available leaf area and thus changes seasonally with leaf phenology, particularly for deciduous plants (Chen et al. 1999; Richardson et al. 2009). Natural and anthropogenic forest disturbances additionally influence growth through the competitive balance for limited resources among trees (Veblen et al. 1994). While this complexity makes it challenging to relate tree-ring data to key carbon cycle functions, it represents an opportunity to assess the combined effects of these mechanisms. In the subsequent sections, we will explore ways in which tree-ring parameters can be combined with other data streams (summarized in Table 1) to address pending process-specific but also integrative research questions. 


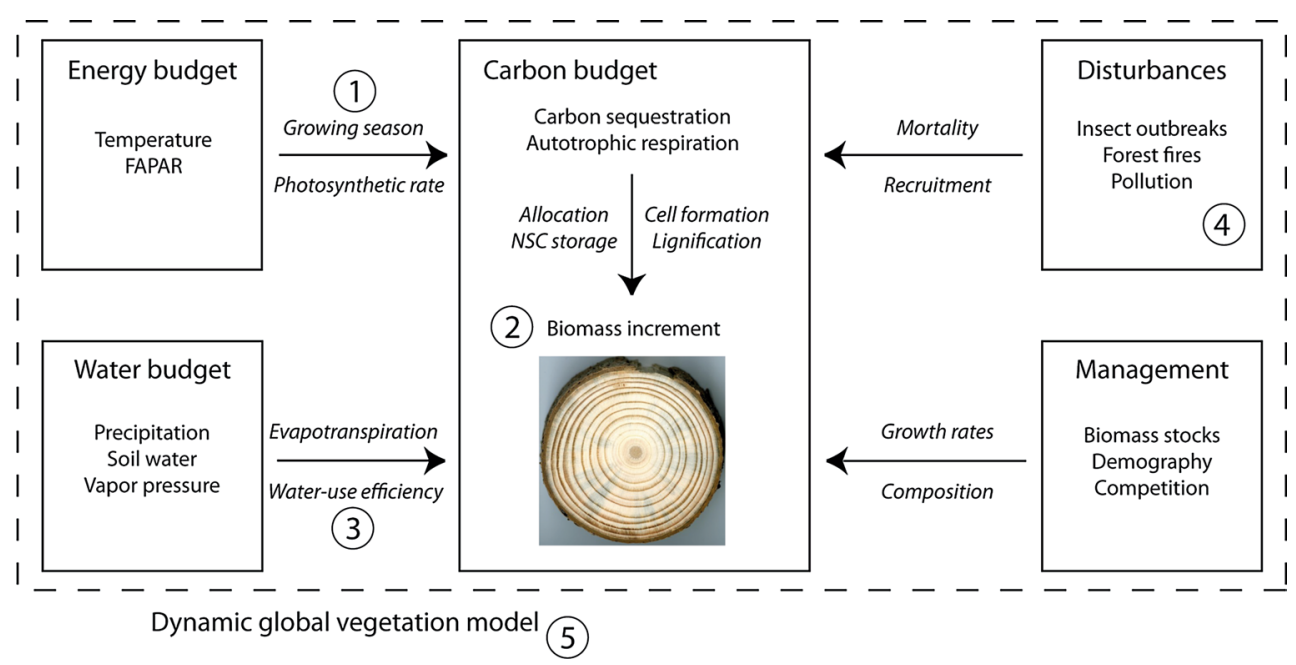

Fig. 1 Schematic view of key drivers and processes (italics) leading to the formation of annual growth rings in woody plants. Numbers refer to the sections in this paper, where the respective aspects are discussed in detail, as follows: 1 "Cambial phenology and growing season", 2 "Forest productivity and carbon allocation", 3 " $\mathrm{CO}_{2}$ fertilization and wateruse efficiency", 4 "Forest disturbances", 5 "Model evaluation and

\section{Cambial phenology and growing season}

The distinct growing and dormant seasons represent one of the most fundamental rhythms characteristic of most forest ecosystems. The growing season can be defined as the period when carbon is actively removed from the atmosphere and assimilated during photosynthesis. Growth seasonality in cold and temperate environments is largely driven by a combination of the photoperiod and climate (Polgar and Primack 2011), whereas tree water status has been identified as the primary driver of leaf phenology and cambial growth in seasonally dry tropical forests (Borchert 1999; Trouet et al. 2012). Comparable studies in tropical rainforests are rare (Dié et al. 2012; Pumijumnong and Buajan 2013). Regardless of climatic growth limitations, a temporal offset between cambial growth and other processes such as leaf formation, photosynthesis, or root and shoot elongation may occur. Such offsets are most evident during growth onset and cessation (Polgar and Primack 2011, and references therein).

Cambial activity in broadleaf ring-porous species (e.g., oak) generally starts multiple weeks prior to bud break (Breda and Granier 1996). The early formation and lignification of large vessels facilitates water transport when the tree reaches a high evapotranspiration demand (i.e. at full leaf expansion) but requires a large investment of nonstructural carbohydrate (NSC) reserves assimilated during the previous growing season (Dietze et al. 2014). This is expressed in tree-ring data as positive lag-1 autocorrelation and/or significant correlations with previous summer to data assimilation". Regarding the section "Model evaluation and data assimilation", please note that not all dynamic global vegetation models include disturbances and management. The displayed stem disc was sampled from a Picea abies individual in Romania (north-eastern Carpathians, $400 \mathrm{~m}$ a.s.l.). FAPAR fraction of absorbed photosynthetically active radiation, $N S C$ non-structural carbohydrates

autumn climate parameters (Babst et al. 2013). The use of NSC for wood formation has also been reported for coniferous or diffuse-porous broadleaf species alike, but with cambial activity starting synchronous with or subsequent to bud break (e.g., in common beech; Cufar et al. 2008). Cambial growth onset typically lags leaf flush in seasonally dry tropical forests, where many tree species are brevi-deciduous and experience a short period of drought-induced deciduousness (Borchert 1999). Cambial activity of these brevi-deciduous species starts much later in the wet season and lasts for only 2-4 months (Trouet et al. 2012). The exact determinism (and definition) of growth onset is still debated, but seems largely controlled by climate (i.e. when temperatures transcend a prescribed threshold; Laube et al. 2014) and hormones (Uggla et al. 1996).

Growth cessation is equally challenging to define and quantify because different mechanisms involved in carbon uptake and wood formation are under different environmental controls (Vaganov et al. 2006) and do not terminate simultaneously (Fig. 2a). Intra-annual tree-ring studies have shown that radial growth typically ceases long before the end of the photosynthetically-active period (King et al. 2013; Moser et al. 2010) and that cell wall-thickening continues after termination of the cambial activity, thereby forming latewood in coniferous species (Fritts 1976). Latewood density in high elevation/latitude conifers is highly temperature sensitive (Esper et al. 2012), integrating influences from meteorological conditions over much of the growing season by the deposition of assimilates in these cell walls. There is also some evidence for late-season 





Fig. 2 Timing of cambial and leaf phenology. The top panel illustrates the relative timing of photosynthetic activity (green) and wood formation (brown) throughout the growing season. The bottom panel demonstrates on the example of a Picea abies individual (Rhone Valley, Central Alps, $800 \mathrm{~m}$ a.s.l.), how intra-annual tree-ring studies can inform on timing of wood formation. Thin sections ( $20 \mu \mathrm{m}$; courtesy of Patrick Fonti) were stained to color lignified cells in red, non-lignified cells in dark blue and cambial cells in light blue. The position of the cambial zone $(C Z)$ and the width of the evolving tree ring (yellow arrows) are indicated (color figure online) (a)

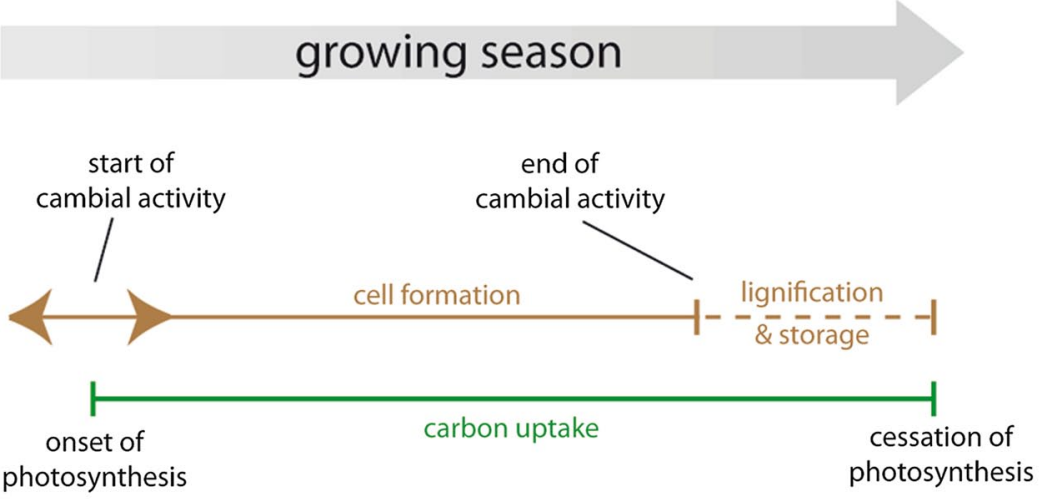

Jun 3, 2009

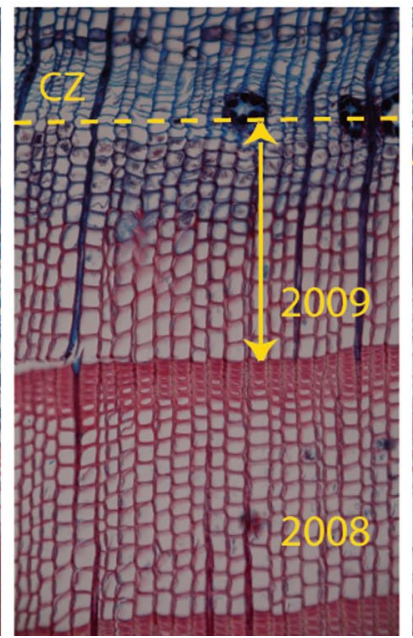

Jul 15, 2009

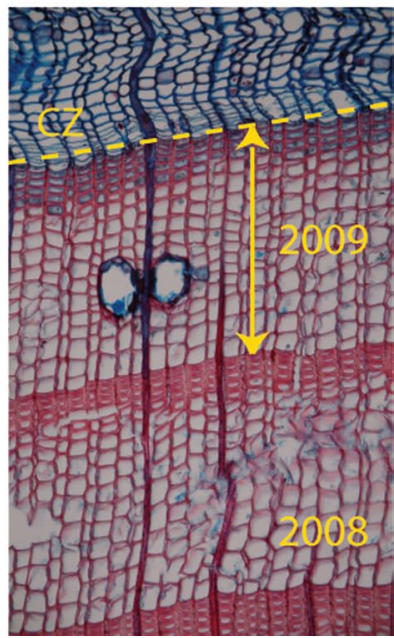

climatic influences on cell enlargement and wall-thickening processes in earlier segments of the annual rings (Franceschini et al. 2012). The formation of intra-annual density fluctuations (local increase in wood density typically induced by summer drought in Mediterranean environments; Campelo et al. 2013) is another example of how carbohydrate investment in cell-wall building continues, while radial growth dramatically slows or even temporarily ceases. These processes consume a significant amount of carbon, which may explain the moderate success of some studies comparing inter-annual variability in radial growth (Granier et al. 2008) and in maximum latewood density (Beck et al. 2013; D'Arrigo et al. 2000) with forest productivity. Accounting for variations in wood density improves the agreement between growth variability and integral measurements of forest carbon uptake (Babst et al. 2014b). Yet, the amount and dynamics of photoassimilates stored in above- and below-ground NSC reserves particularly during cambial dormancy remains a challenging research topic (Dietze et al. 2014), as different types of sugars show high variability throughout the growing and dormant seasons depending upon the cambial developmental stage (Simard et al. 2013).
Disentangling wood formation from canopy phenology is a prerequisite to refine remotely-sensed [e.g., light detection and ranging (LIDAR), vegetation indices, phenology cameras] estimates of forest productivity, as changes in photosynthetic activity do not necessarily reflect changes in cambial growth (Fig. 2a). Intra-annual tree-ring studies involving repeated sampling and wood-anatomical analysis of microcores (known as "punching"; Fig. 2b) are a labor-intensive but promising way to assess the exact timing of these species and biome-specific processes, as well as their impacts on carbon accumulation and use. For instance, Rossi et al. (2014) found an exponential increase in cell production in response to an earlier growth onset in Canadian boreal forests. This is particularly relevant in view of the expected prolongation of the growing season under a warming climate (Richardson et al. 2013). Comparable studies in different climate zones and biomes are needed to accurately test the impacts of rising temperatures on forest productivity.

Forest productivity and carbon allocation

Forests worldwide currently mitigate approximately $30 \%$ of all $\mathrm{CO}_{2}$ emissions from fossil fuel burning and land-use 
changes (Canadell and Raupach 2008; Friedlingstein et al. 2010), thereby dampening the magnitude of global warming. This carbon sink, however, varies considerably in space, time, and magnitude requiring extensive and longterm observational records to assess its dynamics. Forest net primary productivity (NPP) is primarily composed of an above- and a belowground component, the latter of which is particularly difficult to measure accurately. Attempts to do so are very time and labor intensive (Clark et al. 2001), and have thus only been performed in very local studies. Aboveground productivity can more readily be quantified via repeated measurements on permanent plots and remote sensing techniques to determine its contribution to NPP (Clark et al. 2001; Litton et al. 2007). The majority of NPP in forest ecosystems is attributed to tree growth and consecutive inventories of tree biometrics (e.g., changes in diameter, height, and canopy status over a 5- to 10-year period) are commonly used to estimate growth and productivity in countries that have established a systematic inventory. Such monitoring initiatives can be complemented with point and band dendrometers to assess the (intra-)annual variation in tree growth in intensive monitoring plots over multiple years (Etzold et al. 2013; Moore et al. 2006). Yet, growth assessments over more than a few decades are rare (but see Zingg 1996), and also the contributions from temporary changes in water status to changes in tree size can be significant (King et al. 2013; Stephenson et al. 2014).

Tree-ring data contribute to resolving temporal limitations of forest inventories and add a long-term perspective on tree growth prior to the initiation of monitoring activities. Radial growth at breast height has been shown to be representative for the entire stem (Bouriaud et al. 2005), but the strength of inferred climate limitations may decrease toward the crown (van der Maaten-Theunissen and Bouriaud 2012) as carbohydrate allocation to proximal sinks appears favored during stress conditions (Woodruff and Meinzer 2011). In combination with appropriate allometric equations (e.g., Zianis et al. 2005), it is possible to reconstruct tree volume and annual aboveground biomass increment from radial tree growth. Carbon accumulation at the tree-level can be inferred from tree biomass if the wood carbon content is precisely known or reasonably approximated to be $50 \%$ of the wood mass (Joosten et al. 2004). In addition, combining tree-ring-based biomass quantification and wood density data with eddy-covariance (EC) measurements provides information about the partitioning of gross primary productivity (GPP) into soil and tree carbon allocation (i.e. volume increment, cell-wall thickening, storage; Babst et al. 2014b). This approach, however, does not account for the depletion and replenishment of NSC reserves that may partly decouple tree growth from net ecosystem productivity. Current theory suggests that carbon allocation to NSC may be active (i.e. at the expense of growth) or passive (if redundant photoassimilates are available), depending on environmental constraints (Dietze et al. 2014). Empirical quantification of storage mechanisms or dynamics in mature trees (e.g., isotopic tracer experiments; Kuptz et al. 2011) or for entire forest stands is rare.

A series of challenges need to be considered when inferring above-ground forest biomass increment from radial tree growth. First, common dendrochronological sampling designs are often inappropriate for forest productivity estimation, because they rarely reflect the stand structure and density accurately, often lack the necessary biometric and metadata to upscale tree biomass estimates to the site level, and are thus prone to result in biased quantification of growth trends and carbon accumulation (NehrbassAhles et al. 2014). The systematic application of appropriate schemes like the fixed-plot (Babst et al. 2014a; Davis et al. 2009) or random sampling designs at large scales are encouraged to obtain reliable and consistent estimates of above-ground biomass increment and carbon allocation. Second, larger networks are often biased toward areas with strong climatic limitations, facilitating the traditional use of radial growth as a palaeoclimate proxy (Jones et al. 2009). Intensified data collection in temperate regions is thus expected to yield more representative estimates of largescale forest productivity. Tropical regions are also underrepresented, mainly due to the lower proportion of species where ring formation has been demonstrated to be annual. Third, allometric models used to infer above-ground tree biomass from tree dimensions have intrinsic uncertainties that need to be accounted for (Nickless et al. 2011). This issue is not specific to tree-ring studies but equally concerns other biometric approaches based on repeated diameter measurements. Published equations are usually speciesspecific and almost never developed under the exact same site conditions where they are later applied. Finding appropriate biomass functions for specific sites can thus be challenging, but new local parameterization methods making use of the Bayesian approach seem to open perspectives in this respect (Zell et al. 2014). Fourth, tree-ring data reflect the forest structure in the sampling year, whereas temporal changes in forest demography and composition cannot reliably be reconstructed. Uncertainties associated with tree mortality, disturbances, or management increase considerably back in time and are characterized as the "fading record problem". Hence, the site history needs to be considered in stand-level biomass reconstructions and can further be supported by the collection of relict material (Daniels et al. 1997), by responses of surviving trees to formerly present individuals (e.g., growth releases; Rubino and McCarthyz 2004), or by medium-term trends in modeled NPP (Fig. 3). And fifth, upscaling plot level data to larger areas is challenging, especially under variable forest structure and composition. A combination of tree-ring and remotely sensed 

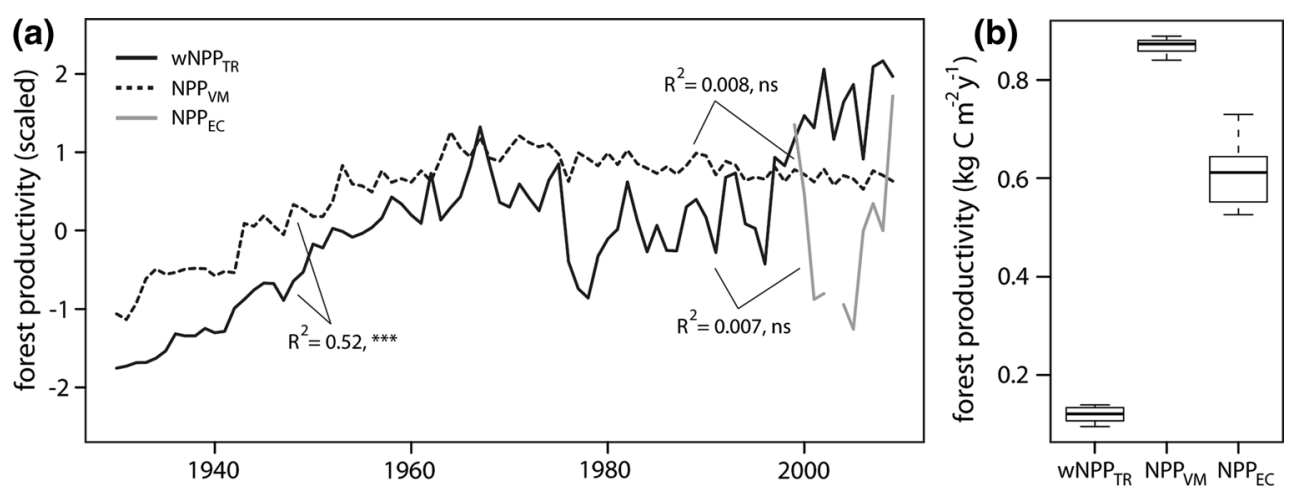

Fig. 3 Example for multiple estimates of forest productivity at the flux-tower site in Braschaat (Belgium). a The inter-annual to decadal variability in woody NPP from tree-rings $\left(w N P P_{T R}\right.$, Pinus sylvestris, source: Babst et al. 2014a), NPP estimates from the ORCHIDEE-FM dynamic global vegetation model $\left(N P P_{V M}\right.$, see Babst et al. 2013, supplementary material for description), and NPP estimates from eddy-

data appears promising to evaluate the extent to which limited-scale records of forest growth reflect landscape or regional vegetation performance. Recently developed remote sensing technologies include airborne or terrestrial LIDAR for high-resolution forest survey (Andersen et al. 2005; Magney et al. 2014) and the use of hyperspectral estimates of physiological parameters for improved modeling of aboveground productivity (Houborg et al. 2013; Smith et al. 2002).

All the above-mentioned approaches have their own advantages, but we find that no single method is able to draw an accurate picture of terrestrial carbon accumulation in woody biomass. The combination of these methods (e.g., as illustrated in Fig. 3) should be aimed at in any study related to forest growth. Some notable examples are Berner et al. (2011), Beck et al. (2013), Poulter et al. (2013), and Bunn et al. (2013), who compared canopy reflectance as expressed by the normalized difference vegetation index (NDVI) and cambial productivity (radial growth and maximum latewood density), or Girardin et al. (2014) who combined inventory, tree-ring, and satellite data to relate recent forest growth to aboveground biomass increment over the past centuries.

$\mathrm{CO}_{2}$ fertilization and water-use efficiency

One of the major uncertainties that will co-determine the fate of the terrestrial carbon cycle in the Anthropocene is the magnitude or even existence of enhanced plant growth at higher $\mathrm{CO}_{2}$ concentrations. Trees regulate the gas exchange at the leaf-level via their stomata in response to environmental conditions and the atmospheric $\mathrm{CO}_{2}$ concentration $\left(\mathrm{c}_{\mathrm{a}}\right)$. This physiological adaptation serves to optimize the ratio between carbon assimilation and covariance data $\left(N P P_{E C}, 50 \%\right.$ of annual GPP as obtained from the European Fluxes database, www.europe-fluxdata.eu) is presented. b Magnitude of the three data streams over the 1999-2009 period. The following significance codes are used for linear regression models: $* * * p<0.001, * * p<0.01, * p \leq 0.05, \mathrm{~ns} p>0.05$

evaporative water loss [water-use efficiency (WUE)] and represents a primary link between plant functioning and anthropogenic perturbations of the carbon cycle (Franks et al. 2013). The rising $c_{a}$ over the industrial period has continuously increased the amount of carbon available for plant photosynthesis (Drake et al. 1997). This has led to a widely debated $\mathrm{CO}_{2}$ fertilization hypothesis, suggesting that an increase in $\mathrm{c}_{\mathrm{a}}$ should exert a positive effect on NPP (Ainsworth and Long 2005). Numerous studies have found a positive relationship between $c_{a}$ and WUE (e.g., Battipaglia et al. 2013; Medlyn et al. 1999), but a related fertilizing effect on tree growth remains highly uncertain. Some studies reported increased growth rates that were hypothesized to be at least partly attributable to $\mathrm{CO}_{2}$ fertilization (Huang et al. 2007; Koutavas 2013; McMahon et al. 2010), whereas other investigations found no such effects (Levesque et al. 2014; Gedalof and Berg 2010; Peñuelas et al. 2011). The absence of a measurable fertilization effect on growth from tree-ring records could be explained, e.g., by secondary limitations that prevent increased $\mathrm{C}$ assimilation from being fully realized (Andreu-Hayles et al. 2011). Furthermore, possible methodological constraints may hinder the clear detection of $\mathrm{CO}_{2}$ fertilization effects in tree rings (Girardin et al. 2011). For instance, the differentiation of $\mathrm{CO}_{2}$-enhanced growth from tree age/size trends in tree-ring width measurements (Frank et al. 2009), classically applied sampling procedures that focus on a selection of dominant individuals (Nehrbass-Ahles et al. 2014), and significant variation in tree-ring data driven by climatic fluctuations may obscure the growth response to $\mathrm{CO}_{2}$. It has also been reported that trees may only benefit from higher $\mathrm{c}_{\mathrm{a}}$ in their early growth phase (Hättenschwiler et al. 1997) or if other resources are not limiting (Norby et al. 2010). In addition, ${ }^{a}{ }^{13} \mathrm{C}$ tracer experiment in mature temperate trees revealed 
that strongly elevated $c_{a}$ led to a higher carbon transfer belowground, whereas photosynthetic capacity and stem growth remained largely unaffected (Körner et al. 2005). The latter finding, while somewhat species-specific, indicates that more carbon is passing through but not remaining in trees under higher $\mathrm{c}_{\mathrm{a}}$.

Tree-ring stable isotope measurements (informing carbon uptake at the leaf level) are a well-established tool that can be used to improve our understanding of $\mathrm{CO}_{2}$-fertilization effects and disentangle ecophysiological processes related to plant water and carbon cycling (Gessler et al. 2009). According to the theory of Farquhar et al. (1982), the ratio between the intercellular $\mathrm{CO}_{2}$ concentration $\left(\mathrm{c}_{\mathrm{i}}\right)$ and $\mathrm{c}_{\mathrm{a}}$ is a proxy for kinetic isotope effects and drives the ${ }^{13} \mathrm{CO}_{2}$ discrimination at the leaf-level. The resulting $\delta^{13} \mathrm{C}$ of photosynthate (with some downstream compound specific fractionation; see below) is imprinted in wood cellulose and thus allows inferring physiological connections to stomatal conductance, WUE, and climatic constraints (Gessler et al. 2009). The quality of these links appears to be stable across scales, as most (but not all; Battipaglia et al. 2013) empirical evidence suggests that plants undergo physiological adaptation to changes in $\mathrm{c}_{\mathrm{a}}$ to keep the relative gradient for $\mathrm{CO}_{2}$ diffusion into the leaf $\left(1-\mathrm{c}_{\mathrm{i}} / \mathrm{c}_{\mathrm{a}}\right)$ close to constant (Franks et al. 2013). Leaf-level effects can, however, be obscured by post-carboxylation fractionation that may occur between $\mathrm{CO}_{2}$ assimilation and allocation of carbohydrates to tree-ring cellulose (Brüggemann et al. 2011; Gessler et al. 2014). As a consequence, $\delta^{13} \mathrm{C}$ may change (1) as photosynthate is moved to and from starch storage pools, (2) prior to and during transport from a leaf to cambial tissue, or (3) during respiration of some fraction of the photosynthate prior to cellulose synthesis (Helle and Schleser 2004; Gessler et al. 2014). Numerous studies, however, have found a strong relationship between treering $\delta^{13} \mathrm{C}$ and climate variables (e.g., Masson-Delmotte et al. 2005), suggesting work is also required to differentiate environmental imprints from $\mathrm{CO}_{2}$ effects.

Separating the impacts of carbon assimilation (demand for $\mathrm{CO}_{2}$ ) and stomatal conductance (supply of $\mathrm{CO}_{2}$ ) based on tree-ring $\delta^{13} \mathrm{C}$ variation alone is challenging. The "dual isotope" concept proposed by Scheidegger et al. (2000) facilitates the interpretation of $\delta^{13} \mathrm{C}$ variation by measuring $\delta^{18} \mathrm{O}$ from the same material. Oxygen isotope variation is viewed as a measure of evaporative flux as it depends on stomatal conductance, but less directly on photosynthetic rates. This dual approach has successfully been used to interpret $\delta^{13} \mathrm{C}$ variation in tree rings (Brooks and Mitchell 2011), but caution must be exercised regarding a number of model assumptions (Roden and Siegwolf 2012). $\delta^{18} \mathrm{O}$ variation in tree-ring cellulose is a function of source water $\delta^{18} \mathrm{O}$, atmospheric humidity (or VPD), atmospheric vapor $\delta^{18} \mathrm{O}$, kinetic and equilibrium fractionation associated with water flux into the leaf, biochemical fractionation during sucrose synthesis, and the proportion of $\mathrm{O}$ that is exchanged with stem water at the site of cellulose synthesis (Roden et al. 2000; Treydte et al. 2014).

The above framework is useful in deriving comparable estimates of both WUE and wood increment and in comparing their inter-annual to decadal variability. Yet, there is evidence that the relationship between WUE and cellulose $\delta^{13} \mathrm{C}$ may be more detectable during periods and/or in regions with relatively frequent and pronounced droughts (Sarris et al. 2013). At the same time, drought conditions lead to stomatal closure, increased NSC utilization (McDowell et al. 2011), and a reduction in carbon uptake and growth, at least partly explaining the absence of a growth increase in response to higher WUE in some earlier studies. Thorough testing of these mechanisms will require large networks of tree-ring stable isotope records that can provide new insight into observed global NPP trends over recent decades (Zhao and Running 2010). Our understanding of how shifts in WUE translate into productivity changes may further be enhanced by combining carbon and oxygen isotope measurements from wood cellulose with EC quantifications of the carbon, water, and energy budgets across ecosystems (Belmecheri et al. 2014).

\section{Forest disturbances}

Natural and anthropogenic forest disturbances and combinations thereof are the primary avenues through which forest ecosystems may be converted from carbon sinks into sources (Veblen et al. 1994), thereby releasing large amounts of carbon into the atmosphere over short time periods. Disturbances resulting from human activities include land-use changes such as deforestation and forest harvesting (Masek et al. 2011), as well as land management practices. The major natural disturbances acting on landscape scales are wildfires (Page et al. 2002), insect defoliation (Hicke et al. 2012), and short-term weather events such as wind and snow storms (Chambers et al. 2007). The carbon cycle responses to forest disturbances are complex and can show non-linear, threshold-like behavior (Breshears and Allen 2002). These responses also involve different time scales, from a carbon source immediately after disturbance to a legacy sink in case of forest regrowth for decades after disturbance. Assessment of disturbance impacts is further complicated by interactions among different types of disturbances (McCullough et al. 1998) and their feedbacks with ongoing and projected climate change (Flannigan et al. 2009; Scholze et al. 2006; Yue et al. 2013). Advanced understanding and quantification of specific disturbance regimes across a range of spatiotemporal scales will serve to improve reconstructions and projections of carbon cycling (Kasischke et al. 2013). 
Land management records (Masek et al. 2011) or remotely sensed data of the affected area (Frolking et al. 2009) have been used to derive spatially extensive estimates for disturbance history. These datasets combined roughly cover the past century (Kasischke et al. 2013) and can be used to quantify disturbance type, frequency (Zeng et al. 2009), seasonal timing (Turetsky et al. 2011), event length (Hogg et al. 2005), spatial extent (Kasischke et al. 2002), intensity (Proulx and Greene 2001), and severity (Turetsky et al. 2011). Disturbance history inferred from tree rings complements land management and satellite records and importantly provides a historical (pre-satellite era or even pre-twentieth century) context for recent disturbance events (Pederson et al. 2014). This is particularly relevant for natural forest disturbances (i.e. wildfire, insect outbreaks, and storms) for which only limited observational data are available at the landscape scale and whose characteristics have changed over time (i.e. pre- vs. post-human settlement) and are expected to continue to change with projected climate trends.

The majority of tree ring-based fire history studies use heat-caused lesions in the boles of surviving trees to date historical low intensity surface fires (Swetnam and Baisan 1996). Tree-ring cross-dating can also be used to date synchronized recruitment events that result from severe crown fires in closed-canopy forests (e.g., Brown and $\mathrm{Wu}$ 2005). These techniques are useful for stand level (Taylor and Skinner 1998) to regional scale (Trouet et al. 2010) assessments, and have advanced our understanding of fire regimes regarding frequency, extent, and seasonality. The long (typically $200+$ years) fire histories allow characterization of fire climatology on inter-annual to multidecadal time-scales (e.g., Swetnam 1993) and assessment of the modulating role of temperature and atmospheric circulation patterns on summer drought (Trouet et al. 2010), spring snowpack duration, and fire season length (Westerling et al. 2006), which regulate fire occurrence and severity. These historical interannual to centennial fire regime dynamics include fire return intervals and fire-climate-vegetation interactions, facets that can be integrated with predictive models to refine projections of ecosystem change under future warming (Kelly et al. 2013).

In a similar way, tree-ring-based reconstructions of insect outbreak occurrences can help elucidate their impact on forest ecosystem dynamics. Forest insect defoliation events often result in decreased tree biomass increment and in wood anatomical changes, and can thus be analyzed using dendrochronological methods (Schweingruber et al. 1979). By compiling tree- and site-level defoliation data, forest insect population dynamics can be studied across spatial and temporal scales (Babst et al. 2010; Speer et al. 2001). Particularly relevant to the study of carbon cycle dynamics are (1) the oscillatory behavior of many forest insect populations and how it is influenced by climate change (Bale et al. 2002) and (2) the interaction between insect outbreaks and other disturbances (e.g., wildfire). Insect population cycles are the result of trophic interactions or maternal effects (Berryman 1996), and treering studies have demonstrated the century-long regularity of these cycles for various insect species (e.g., Boulanger and Arseneault 2004; Esper et al. 2007). In the case of the European larch budmoth, evidence suggests that the absence of peak outbreak events in recent decades may be attributable to anthropogenic warming (Johnson et al. 2010).

A third forest disturbance agent that can be studied using dendrochronological methods is forest blowdown caused by windstorms. Such events can be detected in tree-ring series by identifying growth suppressions resulting from traumatic canopy loss and growth releases in surviving trees that benefit from canopy opening (Hadley and Knapp 2011). Windthrow-related tree growth anomalies compiled at the site and regional level provide evidence for the timing, frequency, and intensity of wind storms and their role on regional forest ecology (Seidl and Blennow 2012). Windstorms modulate forest structure and demography (Harcombe et al. 2004), and have the potential to convert forests from carbon sinks to sources, and then sinks again during recovery (Lindroth et al. 2009). Global climate model projections suggest an increase in extreme wind events and disturbances under future climate scenarios (Blennow and Olofsson 2008). This affects other disturbance agents and can further exacerbate future disturbance regimes. Windstorms interact with wildfire disturbance through the creation of large fuel loads (Weisberg and Swanson 2003) and with insect colonization success through reduced tree growth and vigor related to root and crown damage (Komonen et al. 2011). Such disturbance interactions, as well as decadal- to centennial-scale forest disturbance dynamics, form an important limitation in our understanding of the future role of disturbances in the regional to global forest carbon balance. Tree-ring records from surviving trees can provide a long-term perspective on disturbance dynamics, but provide limited direct information on large-scale mortality and changes in stand density (except death dates and recruitment timing; Pederson et al. 2014).

Model evaluation and data assimilation

Dynamic vegetation models are an essential instrument used to investigate the magnitude and spatiotemporal dynamics of the global terrestrial carbon cycle, upscale in situ observations of ecosystem productivity, and infer and project relevant ecosystem processes (Sitch et al. 2008). Despite the improvements achieved by comparing 
multi-model ensembles (Friedlingstein et al. 2006), persistent challenges continue to hamper reducing the uncertainty in predictions of the forest carbon sink and its response to changes in environmental forcing. Uncertainties may derive from fluctuations in land cover and use (Kaplan et al. 2012), from climatic input data (Poulter et al. 2011), or from model parameters and structure that do not fully capture the spatiotemporal variability in ecosystem processes (Keenan et al. 2012). The latter problem is expressed, e.g., through discrepancies between the observed and simulated climate responses of forests (Babst et al. 2013; Piao et al. 2013), the limited consideration of carry-over effects from the previous growing season typically found in observational growth records (Wettstein et al. 2011), or an unrealistic timing of growth onset and cessation (Kucharik et al. 2006; Richardson et al. 2013).

Constraining vegetation model simulations with in situ observations is a promising method to reduce the above caveats if the uncertainty in both model and observational data is accurately considered (Keenan et al. 2011). Eddycovariance quantification of ecosystem carbon uptake and release have been employed most frequently for this purpose (Beer et al. 2010), but may not be sufficient to constrain medium- to long-term trends in forest carbon accumulation. This is due to (1) the influence of processes and disturbances which are not considered in the models (Keenan et al. 2012), (2) the generally short time series offered by EC measurements and the focus of the EC method on informing fast processes, (3) the unequal abundance of flux towers among different forest types, and (4) the inability to derive carbon allocation patterns from $\mathrm{CO}_{2}$ fluxes measured above the canopy. Tree-ring parameters have rarely been assimilated into carboncycle models, but constraining a process model using biometric estimates of growth led to reductions in parameter uncertainty and improved statistical confidence in model predictions (Richardson et al. 2010). Using treering records to extend estimates of growth over longer periods in model-data fusion exercises should thus be encouraged.

Tree-ring archives are now reaching reasonable global coverage (St. George and Ault 2014; Breitenmoser et al. 2014) and offer valuable opportunities to inform vegetation models about annually resolved and long-term forest growth variability and to some extent disturbances. Largescale growth reductions after disturbances and subsequent recovery need to be considered when past changes in the forest carbon sink are assessed (Bellassen et al. 2011). Hence, potential exists for the use of tree rings to benchmark forest productivity simulations, either through direct comparison of simulated NPP increment with radial growth trends (Malmström et al. 1997) or through comparison of observed versus simulated sensitivities of forests to environmental drivers (Babst et al. 2013). Another interesting path is the possibility to incorporate a process-based model [Vaganov-Shashkin-Lite (VS-lite); Tolwinski-Ward et al. (2011)] to simulate radial tree growth within a fully fledged climate model. The VS-lite model requires only climatic and geographic input data, and this forward modeling approach has been shown to simulate tree-ring chronologies across the globe reasonably well (Breitenmoser et al. 2014). Efforts in modeling radial stem growth from vegetation models will faciliate comparisons between real and simulated tree-ring data (Li et al. 2014). This is crucial, as it will eliminate the need to transform tree-ring data into derived variables such as NPP-a process that introduces new uncertainties-for comparison with or assimilation into modeling frameworks.

\section{Perspectives}

We recognize that no individual discipline or method is capable of conclusively resolving forest carbon cycling at large spatial scales and high temporal resolution. Instead, recent efforts have highlighted the benefits of combining multiple data streams to constrain the spatiotemporal dynamics of forest growth and productivity. Continued efforts to synthesize data products and thereby accumulate the strengths of individual approaches are desirable to improve empirical estimates, model structures, and calibrations and projections of ecosystem functions in a warming world. In this respect, tree rings provide valuable input on multiple temporal scales (Fig. 4), as they continue to be measured worldwide, from arctic environments, where growth is largely happening below ground (Buchwal et al. 2013), to the tropics, where a research focus remains on identifying species and regions where annual rings are formed (Trouet et al. 2012).

Based on our literature review, the following applications of tree-ring archives appear most promising for improving our understanding of terrestrial carbon cycling:

1. Tree-ring quantification of the annual biomass increment can (1) contribute to refining forest carbon budgets, (2) be combined with EC measurements to inform carbon allocation patterns, (3) be used in combination with airborne estimates of forest growth and structure, or (4) improve the temporal resolution of periodical forest inventories. Thereby, consistent sampling schemes are required to produce comparable results across various climate zones and forest types (Babst et al. 2014a; Nehrbass-Ahles et al. 2014).

2. Estimates of WUE based on tree-ring stable isotopes provide information on the response of forest carbon 

scales where tree-ring data can provide information on ecosystem processes. The increment core was sampled from a Picea abies individual in Romania (north-eastern Carpathians, $400 \mathrm{~m}$ a.s.l.)
Fig. 4 Overview of temporal

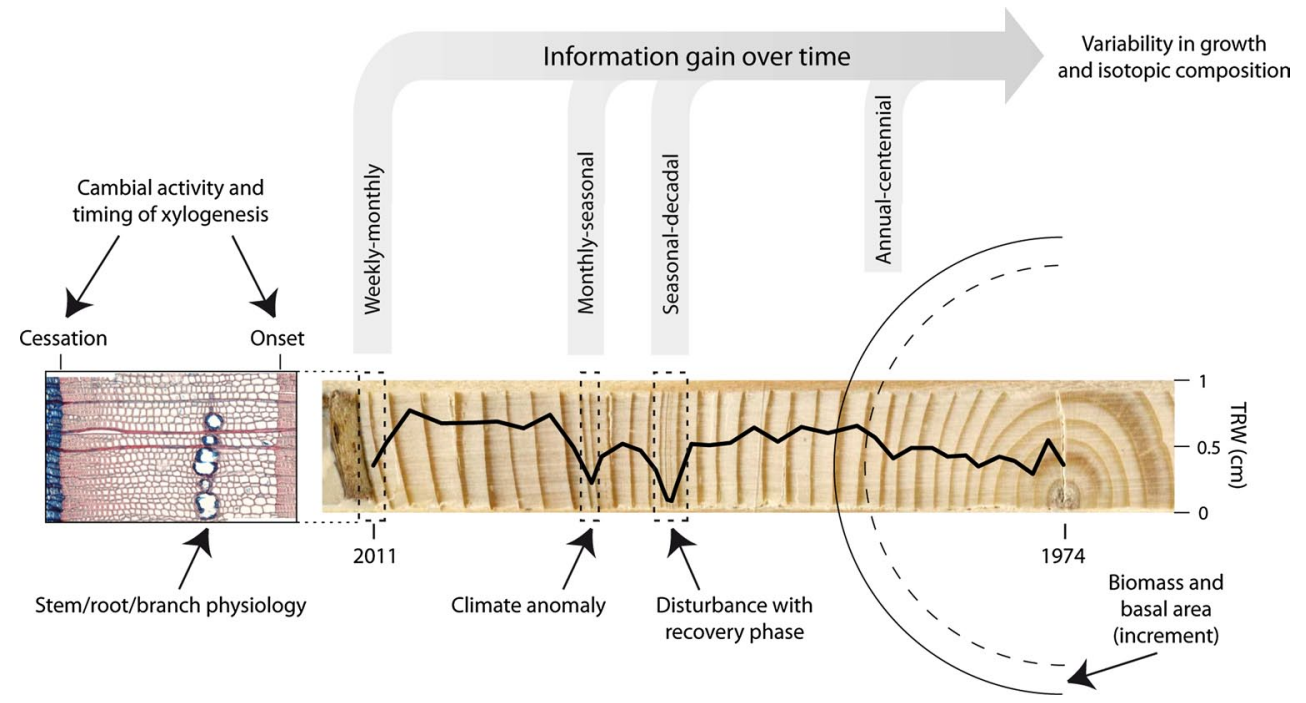

context. Besides reconstructing climate fluctuations (Büntgen et al. 2011; Trouet et al. 2009) or the temperature sensitivity of the atmospheric $\mathrm{CO}_{2}$ concentration (Frank et al. 2010), the long-term perspective offered by tree-ring archives allows the observation of trends in the occurrence of extreme events (Battipaglia et al. 2010). Extreme events can have disproportionally large effects on ecosystems and society, and, as they are rare by definition, require analyses that transcend the timescales captured by instrumental records.

Communication among research communities needs to be further stimulated as a step towards fully harnessing the scientific potential highlighted herein. Carbon-cycle research transcends traditional applications of tree-ring proxies and is only slowly entering the scope of dendrochronology. In turn, the value of tree rings in a carbon context has yet to be fully recognized. Bridging existing gaps is thus inevitable for successful implementation of novel paths of investigation. Furthermore, multidisciplinary collaborations are considerably facilitated by publicly available data from growing international platforms such as FLUXNET or the ITRDB. Contributions to these and other archives can thus only be encouraged as they continuously extend the scales of possible studies and are crucial for maintaining an active dialogue between researchers and with funding agencies. be short-term events such as climate extremes disturbances, which are difficult to predict (Seneviratne 2012), or longer-term changes in the base climate. Tree rings are an instrument to assess (non-)climatic forest growth limitations and can be used, e.g., to benchmark the climate sensitivity of large-scale NPP estimates (Babst et al. 2013).

5. Tree rings provide an opportunity to place current environmental changes into a centennial to millennial
Acknowledgments This work was supported by the Swiss National Science Foundation (Grant PBSKP2_144034) and the US Department of Energy (Grant DE-FOA-000749). O.B. acknowledges funding from project FP7-ENV-2009-1-244122 GHG Europe. The authors thank Patrick Fonti and Gregory King for preparing the thin sections shown in Figs. 2 and 4. We also thank Russell Monson and Alicja Babst-Kostecka for their helpful comments and support. We apologize to all authors whose relevant studies could not be cited. 


\section{References}

Ainsworth EA, Long SP (2005) What have we learned from 15 years of free-air $\mathrm{CO}_{2}$ enrichment (FACE)? A meta-analytic review of the responses of photosynthesis, canopy properties and plant production to rising $\mathrm{CO}_{2}$. New Phytol 165:351-372

Andersen HE, McGaughey RJ, Reutebuch SE (2005) Forest measurement and monitoring using high-resolution airborne lidar. In: Harrington CA, Schoenholtz SH (eds) Productivity of western forests: a forest products focus. Department of Agriculture, Forest Service, Pacific Northwest Research Station, Portland, pp $109-120$

Andreu-Hayles L et al (2011) Long tree-ring chronologies reveal 20th century increases in water-use efficiency but no enhancement of tree growth at five Iberian pine forests. Glob Change Biol 17:2095-2112

Babst F, Esper J, Parlow E (2010) Landsat TM/ETM plus and treering based assessment of spatiotemporal patterns of the autumnal moth (Epirrita autumnata) in northernmost Fennoscandia. Remote Sens Environ 114:637-646

Babst F et al (2013) Above-ground woody carbon sequestration measured from tree rings is coherent with net ecosystem productivity at five eddy-covariance sites. New Phytol 201:1289-1303

Babst F, Bouriaud O, Alexander R, Trouet V, Frank D (2014a) Toward consistent measurements of carbon accumulation: a multi-site assessment of biomass and basal area increment across Europe. Dendrochronologia 32(2):153-161

Babst $F$ et al (2014b) Above-ground woody carbon sequestration measured from tree rings is coherent with net ecosystem productivity at five eddy-covariance sites. New Phytol 201:1289-1303

Bale JS et al (2002) Herbivory in global climate change research: direct effects of rising temperature on insect herbivores. Glob Change Biol 8:1-16

Battipaglia G et al (2010) Five centuries of Central European temperature extremes reconstructed from tree-ring density and documentary evidence. Glob Planet Change 72:182-191

Battipaglia $\mathrm{G}$ et al (2013) Elevated $\mathrm{CO}_{2}$ increases tree-level intrinsic water use efficiency: insights from carbon and oxygen isotope analyses in tree rings across three forest FACE sites. New Phytol 197:544-554

Beck PSA et al (2013) A large-scale coherent signal of canopy status in maximum latewood density of tree rings at arctic tree line in North America. Glob Planet Change 100:109-118

Beer C et al (2010) Terrestrial gross carbon dioxide uptake: global distribution and covariation with climate. Science 329:834-838

Bellassen V, le Maire G, Guin O, Dhote JF, Ciais P, Viovy N (2011) Modelling forest management within a global vegetation model - part 2: model validation from a tree to a continental scale. Ecol Model 222:57-75

Belmecheri S, Maxwell RS, Taylor AH, Davis KJ, Freeman KH, Munger WJ (2014) Tree-ring d13C tracks flux-tower ecosystem productivity estimates in a NE temperate forest. Environ Res Lett 9:074011

Berger T, Köllensperger G, Wimmer R (2004) Plant-soil feedback in spruce (Picea abies) and mixed spruce-beech (Fagus sylvatica) stands as indicated by dendrochemistry. Plant Soil 264:69-83

Berner LT, Beck PSA, Bunn AG, Lloyd AH, Goetz SJ (2011) Highlatitude tree growth and satellite vegetation indices: correlations and trends in Russia and Canada (1982-2008). J Geophys Res Biogeosci 116:G01015

Berryman AA (1996) What causes population cycles of forest Lepidoptera? Trends Ecol Evol 11:28-32

Blennow K, Olofsson E (2008) The probability of wind damage in forestry under a changed wind climate. Clim Change $87: 347-360$
Bonan GB (2008) Forests and climate change: forcings, feedbacks, and the climate benefits of forests. Science 320:1444-1449

Borchert R (1999) Climatic periodicity, phenology, and cambium activity in tropical dry forest trees. IAWA J 20:239-247

Boulanger Y, Arseneault D (2004) Spruce budworm outbreaks in eastern Quebec over the last 450 years. Can J For Res 34:1035-1043

Bouriaud O, Bréda N, Dupouey JL, Granier A (2005) Is ring width a reliable proxy for stem-biomass increment? A case study in European beech. Can J For Res 35:2920-2933

Breda N, Granier A (1996) Intra- and interannual variations of transporation, leaf area index and radial growth of a sessile oak stand (Quercus petraea). Ann For Sci 53:521-536

Breitenmoser P, Brönnimann S, Frank D (2014) Forward modelling of tree-ring width and comparison with a global network of treering chronologies. Clim Past 10:437-449

Breshears DD, Allen CD (2002) The importance of rapid, disturbance-induced losses in carbon management and sequestration. Glob Ecol Biogeogr 11:1-5

Brienen RJW, Zuidema PA (2006) Lifetime growth patterns and ages of Bolivian rain forest trees obtained by tree ring analysis. J Ecol 94:481-493

Briffa KR, Osborn TJ, Schweingruber FH, Jones PD, Shiyatov SG, Vaganov EA (2002) Tree-ring width and density data around the Northern Hemisphere: part 1, local and regional climate signals. Holocene 12:737-757

Brooks JR, Mitchell AK (2011) Interpreting tree responses to thinning and fertilization using tree-ring stable isotopes. New Phytol 190:770-782

Brown PM, Wu R (2005) Climate and disturbance forcing of episodic tree recruitment in a southwestern ponderosa pine landscape. Ecology 86:3030-3038

Brüggemann $\mathrm{N}$ et al (2011) Carbon allocation and carbon isotope fluxes in the plant-soil-atmosphere continuum: a review. Biogeosciences 8:3457-3489

Buchwal A, Rachlewicz G, Fonti P, Cherubini P, Gärtner H (2013) Temperature modulates intra-plant growth of Salix polaris from a high Arctic site (Svalbard). Polar Biol 36:1305-1318

Bunn AG et al (2013) Comparing forest measurements from tree rings and a space-based index of vegetation activity in Siberia. Environ Res Lett 8:035034

Büntgen U et al (2011) 2500 years of European climate variability and human susceptibility. Science 331:578-582

Campbell R, McCarroll D, Loader NJ, Grudd H, Robertson I, Jalkanen R (2007) Blue intensity in Pinus sylvestris tree-rings: developing a new palaeoclimate proxy. Holocene 17:821-828

Campelo F, Vieira J, Nabais C (2013) Tree-ring growth and intraannual density fluctuations of Pinus pinaster responses to climate: does size matter? Trees 27:763-772

Canadell JG, Raupach MR (2008) Managing forests for climate change mitigation. Science 320:1456-1457

Chambers JQ, Fisher JI, Zeng H, Chapman EL, Baker DB, Hurtt GC (2007) Hurricane Katrina's carbon footprint on US Gulf coast forests. Science 318:1107

Chen JM, Liu J, Cihlar J, Goulden ML (1999) Daily canopy photosynthesis model through temporal and spatial scaling for remote sensing applications. Ecol Model 124:99-119

Clark DA, Brown S, Kicklighter DW, Chambers JQ, Thomlinson JR, Ni J (2001) Measuring net primary production in forests: concepts and fiels methods. Ecol Appl 11:356-370

Collatz GJ, Ball JT, Grivet C, Berry JA (1991) Physiological and environmental regulation of stomatal conductance, photosynthesis and transpiration: a model that includes a laminar boundary layer. Agric For Meteorol 54:107-136

Cufar K, Prislan P, de Luis M, Gricar J (2008) Tree-ring variation, wood formation and phenology of beech (Fagus sylvatica) from 
a representative site in Slovenia, SE Central Europe. TreesStruct Funct 22:749-758

Cuny H, Rathgeber C, Frank D, Fonti P, Fournier M (2014) Kinetics of tracheid development explain conifer tree-ring structure. New Phytol. doi:10.1111/nph.12871

Daniels LD, Dobry J, Klinka K, Feller MC (1997) Determining year of death of logs and snags of Thuja plicata in southwestern coastal British Columbia. Can J For Res 27:1132-1141

D'Arrigo RD, Malmstrom CM, Jacoby GC, Los SO, Bunker DE (2000) Correlation between maximum latewood density of annual tree rings and NDVI based estimates of forest productivity. Int J Remote Sens 21:2329-2336

Davis SC, Hessl AE, Scott CJ, Adams MB, Thomas RB (2009) Forest carbon sequestration changes in response to timber harvest. For Ecol Manag 258:2101-2109

Dié A, Kitin P, Kouame FNG, Van den Bulcke J, Van Acker J, Beeckman $H$ (2012) Fluctuations of cambial activity in relation to precipitation result in annual rings and intra-annual growth zones of xylem and phloem in teak (Tectona grandis) in Ivory Coast. Ann Bot 110:861-873

Dietze MC et al (2014) Nonstructural carbon in woody plants. Annu Rev Plant Biol 65:667-687

Drake BG, Gonzàlez-Meler MA, Long SP (1997) More efficient plants: a consequence of rising atmospheric $\mathrm{CO}_{2}$ ? Annu Rev Plant Physiol Plant Mol Biol 48:609-639

Drever CR, Lertzman KP (2001) Light-growth responses of coastal Douglas-fir and western redcedar saplings under different regimes of soil moisture and nutrients. Can J For Res 31:2124-2133

Esper J, Buntgen U, Frank DC, Nievergelt D, Liebhold A (2007) 1200 years of regular outbreaks in alpine insects. Proc R Soc Lond B 274:671-679

Esper J et al (2012) Orbital forcing of tree-ring data. Nat Clim Change 2:862-866

Etzold S, Zweifel R, Ruehr NK, Eugster W, Buchmann N (2013) Long-term stem $\mathrm{CO}_{2}$ concentration measurements in Norway spruce in relation to biotic and abiotic factors. New Phytol 197:1173-1184

Fahey TJ et al (2009) Forest carbon storage: ecology, management, and policy. Front Ecol Environ 8:245-252

Farquhar GD, von Caemmerer S (1982) Modelling of photosynthetic response to environmental conditions. Physiological plant ecology II, vol 12/B. Springer, Berlin, pp 549-587

Flannigan MD, Krawchuk MA, de Groot WJ, Wotton BM, Gowman LM (2009) Implications of changing climate for global wildland fire. Int J Wildland Fire 18:483-507

Franceschini $\mathrm{T}$ et al (2012) Empirical models for radial and tangential fibre width in tree rings of Norway spruce in north-western Europe. Holzforschung 66:219-230

Frank DC, Büntgen U, Esper J (2009) Comment on "late 20th century growth acceleration in Greek firs (Abies cephalonica) from Cephalonica Island, Greece: a $\mathrm{CO}_{2}$ fertilization effect?". Dendrochronologia 27:223-227

Frank DC et al (2010) Ensemble reconstruction constraints on the global carbon cycle sensitivity to climate. Nature 463:527-U143

Franks PJ, Adams M, Amthor J, Barbour M, Berry JA, Ellsworth DS, Farquhar GD, Ghannoum O, Lloyd J, McDowell N, Norby R, Tissue D, von Caemmerer S (2013) Sensitivity of plants to changing atmospheric $\mathrm{CO}_{2}$ concentration: from the geological past to the next century. New Phytol 197:1077-1094

Friedlingstein P et al (2006) Climate-carbon cycle feedback analysis: results from the C4MIP model intercomparison. J Clim 19:3337-3353

Friedlingstein $\mathrm{P}$ et al (2010) Update on $\mathrm{CO}_{2}$ emissions. Nat Geosci 3:811-812
Fritts HC (1976) Tree rings and climate. Blackburn, Caldwell

Frolking S, Palace MW, Clark DB, Chambers JQ, Shugart HH, Hurtt GC (2009) Forest disturbance and recovery: a general review in the context of spaceborne remote sensing of impacts on aboveground biomass and canopy structure. J Geophys Res Biogeosci 114:G00E02

Gedalof Z, Berg AA (2010) Tree ring evidence for limited direct $\mathrm{CO}_{2}$ fertilization of forests over the 20th century. Glob Biogeochem Cycl 24:GB3027

Gessler A, Brandes E, Buchmann N, Helle G, Rennenberg H, Barnard RL (2009) Tracing carbon and oxygen isotope signals from newly assimilated sugars in the leaves to the tree-ring archive. Plant Cell Environ 32:780-795

Gessler A, Ferrio JP, Hommel R, Treydte K, Werner RA, Monson RK (2014) Stable isotopes in tree rings: towards a mechanistic understanding of isotope fractionation and mixing processes from the leaves to the wood. Tree Physiol. doi:10.1093/treephy s/tpu040

Girardin MP, Bernier PY, Raulier F, Tardif JC, Conciatori F, Guo XJ (2011) Testing for a $\mathrm{CO}_{2}$ fertilization effect on growth of Canadian boreal forests. J Geophys Res 116:G01012

Girardin MP, Guo XJ, De Jong R, Kinnard C, Bernier P, Raulier F (2014) Unusual forest growth decline in boreal North America covaries with the retreat of Arctic sea ice. Glob Change Biol 20:851-866

Granier A, Bréda N, Longdoz B, Gross P, Ngao J (2008) Ten years of fluxes and stand growth in a young beech forest at Hesse Northeastern France. Ann For Sci 65:704

Hadley KS, Knapp PA (2011) Detection of high-wind events using tree-ring data. Can J For Res 41:1121-1129

Harcombe PA, Greene SE, Kramer MG, Acker SA, Spies TA, Valentine $\mathrm{T}$ (2004) The influence of fire and windthrow dynamics on a coastal spruce-hemlock forest in Oregon, USA, based on aerial photographs spanning 40 years. For Ecol Manag 194:71-82

Hättenschwiler S, Miglietta F, Raschi A, Koner C (1997) Thirty years of in situ tree growth under elevated $\mathrm{CO}_{2}$ : a model for future forest responses? Glob Change Biol 3:463-471

Helle G, Schleser GH (2004) Beyond $\mathrm{CO}_{2}$-fixation by Rubisco-an interpretation of $13 \mathrm{C} / 12 \mathrm{C}$ variations in tree rings from novel intra-seasonal studies on broad-leaf trees. Plant Cell Environ 27:367-380

Hicke JA et al (2012) Effects of biotic disturbances on forest carbon cycling in the United States and Canada. Glob Change Biol 18:7-34

Hogg EH, Brandt JP, Kochtubajda B (2005) Factors affecting interannual variation in growth of western Canadian aspen forests during 1951-2000. Can J For Res 35:610-622

Houborg R, Cescatti A, Migliavacca M, Kustas WP (2013) Satellite retrievals of leaf chlorophyll and photosynthetic capacity for improved modeling of GPP. Agric For Meteorol 177:10-23

Huang J-G, Bergeron Y, Denneler B, Berninger F, Tardif J (2007) Response of forest trees to increased atmospheric $\mathrm{CO}_{2}$. Crit Rev Plant Sci 26:265-283

Johnson D, Büntgen U, Frank DC, Kausrud K, Haynes K, Liebhold A, Esper J, Stenseth NC (2010) Climatic warming disrupts recurrent Alpine insect outbreaks. Proc Natl Acad Sci USA 107:20576-20581

Jones PD et al (2009) High-resolution palaeoclimatology of the last millennium: a review of current status and future prospects. Holocene 19:3-49

Jones $\mathrm{C}$ et al (2013) 21st century compatible $\mathrm{CO}_{2}$ emissions and airborne fraction simulated by CMIP5 earth system models under 4 representative concentration pathways. J Clim 26:4398-4413

Joosten R, Schumacher J, Wirth C, Schulte A (2004) Evaluating tree carbon predictions for beech (Fagus sylvatica L.) in western Germany. For Ecol Manag 189:87-96 
Kaplan JO, Krumhardt KM, Zimmermann NE (2012) The effects of land use and climate change on the carbon cycle of Europe over the past 500 years. Glob Change Biol 18:902-914

Kasischke ES, Williams D, Barry D (2002) Analysis of the patterns of large fires in the boreal forest region of Alaska. Int J Wildland Fire 11:131-144

Kasischke ES et al (2013) Impacts of disturbance on the terrestrial carbon budget of North America. J Geophys Res Biogeosci 118:303-316

Keenan T, Carbone M, Reichstein M, Richardson A (2011) The model-data fusion pitfall: assuming certainty in an uncertain world. Oecologia 167:587-597

Keenan TF, Davidson E, Moffat AM, Munger W, Richardson AD (2012) Using model-data fusion to interpret past trends, and quantify uncertainties in future projections, of terrestrial ecosystem carbon cycling. Glob Change Biol 18:2555-2569

Kelly R, Chipman ML, Higuera PE, Stefanova I, Brubaker LB, Hu FS (2013) Recent burning of boreal forests exceeds fire regime limits of the past 10,000 years. Proc Natl Acad Sci USA 110:13055-13060

King G, Fonti P, Nievergelt D, Büntgen U, Frank D (2013) Climatic drivers of hourly to yearly tree radius variations along a $6^{\circ} \mathrm{C}$ natural warming gradient. Agric For Meteorol 168:36-46

Komonen A, Schroeder LM, Weslien J (2011) Ips typographus population development after a severe storm in a nature reserve in southern Sweden. J Appl Entomol 135:132-141

Körner C, Asshoff R, Bignucolo O, Hättenschwiler S, Keel SG, Pelaez-Riedl S, Pepin S, Siegwolf R, Zotz G (2005) Carbon flux and growth in mature deciduous forest trees exposed to elevated $\mathrm{CO}_{2}$. Science 309:1360-1362

Koutavas A (2013) $\mathrm{CO}_{2}$ fertilization and enhanced drought resistance in Greek firs from Cephalonia Island, Greece. Glob Change Biol 19:529-539

Kucharik CJ, Barford CC, Maayar ME, Wofsy SC, Monson RK, Baldocchi DD (2006) A multiyear evaluation of a dynamic global vegetation model at three AmeriFlux forest sites: vegetation structure, phenology, soil temperature, and $\mathrm{CO}_{2}$ and $\mathrm{H}_{2} \mathrm{O}$ vapor exchange. Ecol Model 196:1-31

Kuptz D, Fleischmann F, Matyssek R, Grams T (2011) Seasonal patterns of carbon allocation to respiratory pools in 60-year-old deciduous (Fagus sylvatica) and evergreen (Picea abies) trees assessed via whole-tree stable carbon isotope labeling. New Phytol 191:160-172

Laube J, Sparks TH, Estrella N, Höfler J, Ankerst DP, Menzel A (2014) Chilling outweighs photoperiod in preventing precocious spring development. Glob Change Biol 20:170-182

Law B (2013) Biogeochemistry: nitrogen deposition and forest carbon. Nature 496:307-308

Le Quéré C et al (2013) The global carbon budget 1959-2011. Earth Syst Sci Data Discuss 5:1107-1157

Levesque M, Siegwolf R, Saurer M, Eilmann B, Rigling A (2014) Increased water-use efficiency does not lead to enhanced tree growth under xeric and mesic conditions. New Phytol 203:94-109

Li G, Harrison SP, Prentice IC, Falster D (2014) Simulation of tree ring-widths with a model for primary production, carbon allocation and growth. Biogeosci Discuss 11:10451-10485

Lindroth A et al (2009) Storms can cause Europe-wide reduction in forest carbon sink. Glob Change Biol 15:346-355

Litton CM, Raich JW, Ryan MG (2007) Carbon allocation in forest ecosystems. Glob Change Biol 13:2089-2109

Magney TS, Eusden SA, Eitel JUH, Logan BA, Jiang J, Vierling LA (2014) Assessing leaf photoprotective mechanisms using terrestrial LiDAR: towards mapping canopy photosynthetic performance in three dimensions. New Phytol 201:344-356
Malmström CM, Thompson MV, Juday GP, Los SO, Randerson JT, Field CB (1997) Interannual variation in global-scale net primary production: testing model estimates. Glob Biogeochem Cycl 11:367-392

Masek JG et al (2011) Recent rates of forest harvest and conversion in North America. J Geophys Res Biogeosci 116:G00K03

Masson-Delmotte V et al (2005) Changes in European precipitation seasonality and in drought frequencies revealed by a fourcentury-long tree-ring isotopic record from Brittany, western France. Clim Dyn 24:57-69

McCullough DG, Werner RA, Neumann D (1998) Fire and insects in Northern and Boreal forest ecosystems of North America1. Annu Rev Entomol 43:107-127

McDowell NG, Beerling DJ, Breshears DD, Fisher RA, Raffa KF, Stitt M (2011) The interdependence of mechanisms underlying climate-driven vegetation mortality. Trends Ecol Evol 26:523-532

McMahon SM, Parker GG, Miller DR (2010) Evidence for a recent increase in forest growth. Proc Natl Acad Sci USA 107:3611-3615

Medlyn BE et al (1999) Effects of elevated $\left[\mathrm{CO}_{2}\right]$ on photosynthesis in European forest species: a meta-analysis of model parameters. Plant Cell Environ 22:1475-1495

Moore DJP, Aref S, Ho RM, Pippen JS, Hamilton JG, De Lucia EH (2006) Annual basal area increment and growth duration of Pinus taeda in response to eight years of free-air carbon dioxide enrichment. Glob Change Biol 12:1367-1377

Moser L et al (2010) Timing and duration of European larch growing season along altitudinal gradients in the Swiss Alps. Tree Physiol 30:225-233

Nehrbass-Ahles C et al (2014) The influence of sampling design on tree-ring based quantification of forest growth. Glob Change Biol. doi:10.1111/gcb.12599

Nickless A, Scholes RJ, Archibald S (2011) A method for calculating the variance and confidence intervals for tree biomass estimates obtained from allometric equations : research article. S Afr J Sci 107:1-10

Norby RJ, Warren JM, Iversen CM, Medlyn BE, McMurtrie RE (2010) $\mathrm{CO}_{2}$ enhancement of forest productivity constrained by limited nitrogen availability. Proc Natl Acad Sci USA 107:19368-19373

Page SE, Siegert F, Rieley JO, Boehm H-DV, Jaya A, Limin S (2002) The amount of carbon released from peat and forest fires in Indonesia during 1997. Nature 420:61-65

Pan Y et al (2011) A large and persistent carbon sink in the world's forests. Science 333:988-993

Pederson N et al (2014) The legacy of episotic climatic events in shaping temperate, broadleaf forests. Ecol Monogr. http://dx.doi .org/10.1890/13-1025.1

Peñuelas J, Canadell JG, Ogaya R (2011) Increased water-use efficiency during the 20th century did not translate into enhanced tree growth. Glob Ecol Biogeogr 20:597-608

Piao S et al (2013) Evaluation of terrestrial carbon cycle models for their response to climate variability and to $\mathrm{CO}_{2}$ trends. Glob Change Biol 19:2117-2132

Polgar CA, Primack RB (2011) Leaf-out phenology of temperate woody plants: from trees to ecosystems. New Phytol 191:926-941

Poulter B, Frank DC, Hodson EL, Zimmermann NE (2011) Impacts of land cover and climate data selection on understanding terrestrial carbon dynamics and the $\mathrm{CO}_{2}$ airborne fraction. Biogeosciences 8:2027-2036

Poulter B et al (2013) Recent trends in Inner Asian forest dynamics to temperature and precipitation indicate high sensitivity to climate change. Agric For Meteorol 178-179:31-45 
Poulter B, Frank D, Ciais P, Myneni RB, Andela N, Bi J, Broquet G, Canadell JG, Chevallier F, Liu YY, Running S, sitch S, van der Werf GR (2014) Contribution of semi-arid ecosystems to interannual variability of the global carbon cycle. Nature. doi: 10.1038 /nature13376

Proulx OJ, Greene DF (2001) The relationship between ice thickness and northern hardwood tree damage during ice storms. Can J For Res 31:1758-1767

Pumijumnong N, Buajan S (2013) Seasonal cambial activity of five tropical tree species in central Thailand. Trees 27:409-417

Reichstein M et al (2013) Climate extremes and the carbon cycle. Nature 500:287-295

Richardson AD, Hollinger DY, Dail DB, Lee JT, Munger JW, O'keefe $\mathrm{J}$ (2009) Influence of spring phenology on seasonal and annual carbon balance in two contrasting New England forests. Tree Physiol 29:321-331

Richardson A et al (2010) Estimating parameters of a forest ecosystem $\mathrm{C}$ model with measurements of stocks and fluxes as joint constraints. Oecologia 164:25-40

Richardson AD, Keenan TF, Migliavacca M, Ryu Y, Sonnentag O, Toomey M (2013) Climate change, phenology, and phenological control of vegetation feedbacks to the climate system. Agric For Meteorol 169:156-173

Roden J, Siegwolf R (2012) Is the dual-isotope conceptual model fully operational? Tree Physiol 32:1179-1182

Roden JS, Lin G, Ehleringer JR (2000) A mechanistic model for interpretation of hydrogen and oxygen isotope ratios in tree-ring cellulose. Geochim Cosmochim Acta 64:21-35

Rossi S, Girard MJ, Morin H (2014) Lengthening of the duration of xylogenesis engenders disproportionate increases in xylem production. Glob Change Biol 20:2261-2271

Rubino DL, McCarthyz BC (2004) Comparative analysis of dendroecological methods used to assess disturbance events. Dendrochronologia 21:97-115

Running SW (2008) Ecosystem disturbance, carbon, and climate. Science 321:652-653

Sarris D, Siegwolf R, Körner C (2013) Inter- and intra-annual stable carbon and oxygen isotope signals in response to drought in Mediterranean pines. Agric For Meteorol 168:59-68

Scheidegger Y, Saurer M, Bahn M, Siegwolf R (2000) Linking stable oxygen and carbon isotopes with stomatal conductance and photosynthetic capacity: a conceptual model. Oecologia 125:350-357

Scholze M, Knorr W, Arnell NW, Prentice IC (2006) A climatechange risk analysis for world ecosystems. Proc Natl Acad Sci USA 103:13116-13120

Schweingruber FH, Braker OU, Schar E (1979) Dendro-climatic studies on conifers from central Europe and Great Britain. Boreas $8: 427-452$

Seidl R, Blennow K (2012) Pervasive growth reduction in norway spruce forests following wind disturbance. PLoS ONE 7:e33301

Seneviratne SI (2012) Climate science: historical drought trends revisited. Nature 491:338-339

Simard S et al (2013) Intra-annual dynamics of non-structural carbohydrates in the cambium of mature conifer trees reflects radial growth demands. Tree Physiol 33:913-923

Sitch S et al (2008) Evaluation of the terrestrial carbon cycle, future plant geography and climate-carbon cycle feedbacks using five dynamic global vegetation models (DGVMs). Glob Change Biol 14:2015-2039

Smith M-L, Ollinger SV, Martin ME, Aber JD, Hallett RA, Goodale CL (2002) Direct estimation of aboveground forest productivity through hyperspectral remote sensing of canopy nitrogen. Ecol Appl 12:1286-1302

Speer JH, Swetnam TW, Wickman BE, Youngblood A (2001) Changes in pandora moth outbreak dynamics during the past 622 years. Ecology 82:679-697
St. George S, Ault TR (2014) The imprint of climate within Northern Hemisphere trees. Quatern Sci Rev 89:1-4

Stephenson NL, Das AJ, condit R et al (2014) Rate of tree carbon accumulation increases continuously with tree size. Nature 507:90-93

Swetnam TW (1993) Fire history and climate change in Giant Sequoia Groves. Science 262:885-889

Swetnam TW, Baisan CH (1996) Fire histories of Montane forests in the Madrean borderlands. In: Ffolliott PF et al. (eds) Effects of fire on madrean province ecosystems - a symposium proceedings, vol 289, pp 15-36

Taylor AH, Skinner CN (1998) Fire history and landscape dynamics in a late-successional reserve, Klamath Mountains, California, USA. For Ecol Manag 111:285-301

Tolwinski-Ward SE, Evans MN, Hughes MK, Anchukaitis KJ (2011) An efficient forward model of the climate controls on interannual variation in tree-ring width. Clim Dyn 36:2419-2439

Treydte K, Boda S, Pannatier EG, Fonti P, Frank D, Ullrich B, Saurer M, Siegwolf R, Battipaglia G, Werner W, Gessler A (2014) Seasonal transfer of oxygen isotopes from precipitation and soil to the tree ring: source water versus needle water enrichment. New Phytol. doi:10.1111/nph.12741

Trouet V, Esper J, Graham NE, Baker A, Scourse JD, Frank DC (2009) Persistent Positive North Atlantic oscillation mode dominated the medieval climate anomaly. Science 324:78-80

Trouet V, Taylor AH, Wahl ER, Skinner CN, Stephens SL (2010) Fireclimate interactions in the American West since 1400 CE. Geophys Res Lett 37:L04702

Trouet V, Mukelabai M, Verheyden A, Beeckman H (2012) Cambial Growth Season of Brevi-Deciduous Brachystegia spiciformis trees from South Central Africa restricted to less than four months. PLoS ONE 7:e47364

Turetsky MR et al (2011) Recent acceleration of biomass burning and carbon losses in Alaskan forests and peatlands. Nat Geosci 4:27-31

Uggla C, Moritz T, Sandberg G, Sundberg B (1996) Auxin as a positional signal in pattern formation in plants. Proc Natl Acad Sci USA 93:9282-9286

Vaganov EA, Hughes MK, Shashkin AV (2006) Growth dynamics of conifer tree rings. Springer, Berlin

van der Maaten-Theunissen M, Bouriaud O (2012) Climate-growth relationships at different stem heights in silver fir and Norway spruce. Can J For Res 42:958-969

Veblen TT, Hadley KS, Nel EM, Kitzberger T, Reid M, Villalba R (1994) Disturbance regime and disturbance interactions in a rocky mountain Subalpine forest. J Ecol 82:125-135

Weber P, Bugmann H, Fonti P, Rigling A (2008) Using a retrospective dynamic competition index to reconstruct forest succession. For Ecol Manag 254:96-106

Weisberg PJ, Swanson FJ (2003) Regional synchroneity in fire regimes of western Oregon and Washington, USA. For Ecol Manag 172:17-28

Westerling AL, Hidalgo HG, Cayan DR, Swetnam TW (2006) Warming and earlier spring increase western US forest wildfire activity. Science 313:940-943

Wettstein JJ, Littell JS, Wallace JM, Gedalof Ze (2011) Coherent region-, species-, and frequency-dependent local climate signals in Northern Hemisphere tree-ring widths. J Clim 24:5998-6012

Woodruff DR, Meinzer FC (2011) Water stress, shoot growth and storage of non-structural carbohydrates along a tree height gradient in a tall conifer. Plant Cell Environ 34:1920-1930

Yue C et al (2013) Simulating boreal forest carbon dynamics after stand-replacing fire disturbance: insights from a global processbased vegetation model. Biogeosci Discuss 10:7299-7366

Zell J, Bösch B, Kändler G (2014) Estimating above-ground biomass of trees: comparing Bayesian calibration with regression technique. Eur J For Res 133:649-660 
Zeng H, Chambers JQ, Negrón-Juárez RI, Hurtt GC, Baker DB, Powell MD (2009) Impacts of tropical cyclones on US forest tree mortality and carbon flux from 1851 to 2000. Proc Natl Acad Sci USA 106:7888-7892

Zhao M, Running SW (2010) Drought-induced reduction in Global terrestrial net primary production from 2000 through 2009. Science 329:940-943
Zianis D, Muukkonen P, Makipaa R, Mencuccini M (2005) Biomass and stem volume equations for tree species in Europe. Silva Fenn Monogr 4:1-63

Zingg A (1996) Diameter and basal area increment in permanent growth and yield plots in Switzerland. In: Spiecker H, Mielikäinen K, Köhl M, Skovsgaard JP (eds) Growth trends in European forests. Springer, Berlin, pp 239-265 